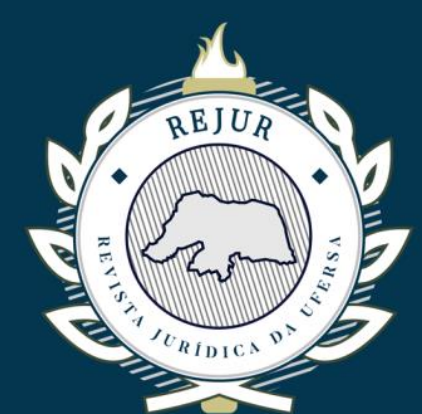

\title{
ANÁLISE SOBRE O INTERROGATÓRIO JUDICIAL NA LEI DE DROGAS: CONFLITO DOS PRINCÍPIOS DA ESPECIALIDADE, DO CONTRADITÓRIO E DA AMPLA DEFESA
}

ANALYSIS ON THE COURT INTERROGATORY IN DRUG LAW: CONFLICT BETWEEN PRINCIPLES OF SPECIALITY, ADVERSARIAL PROCEDURE AND FULL DEFENSE

\section{Danilo Henrique Nunes* | Jonatas dos Santos Silva** | Adélcio Ramos da Cruz***}

\section{RESUMO}

A atual Lei 11.343/2006 é o instrumento normativo competente para tratar sobre situações que envolvam drogas ilícitas, seja na sua questão material ou processual. Mediante esta informação, cabe apontar que o presente estudo tem como objetivo tratar sobre situações conflitantes entre normas especiais (tratadas pela supradita lei) e demais princípios constitucionais gerais (ampla defesa e contraditório), mas que por sua vez encontram meios para atuação no procedimento penal. Com a apresentação de uma revisão bibliográfica sobre o tema proposto, busca-se a apresentação de forma construtiva sobre a regulamentação legal e a sua aplicação nos procedimentos processuais. A metodologia utilizada neste trabalho por sua vez, além da revisão acima narrada, utilizou-se de artigos científicos, jurisprudência e legislações processuais, sejam elas vigentes ou revogadas. Ou seja, guiou-se pelo método dedutivo, e que de forma significativa resulta na conclusão que quando possível, o princípio da especialidade deve ser respeitado e utilizado, mas não para este caso em tela, já que a ampla defesa e o contraditório, além de princípios estruturantes do Estado Democrático de Direito, é nada mais, nada menos que um defensor da dignidade daqueles que estão nos átrios brasilianos.

Palavras-chave: Lei de Drogas; interrogatório judicial; conflito de princípios; mitigação; especialidade.

\section{ABSTRACT}

The current Law 11.343 / 2006 is the competent normative instrument to deal with situations involving illicit drugs, whether in its material or procedural issue. Through this information, it is worth pointing out that the present study aims to deal with conflicting situations between special rules (dealt with by the aforementioned law) and other general constitutional principles (broad defense and contradictory), but which in turn find ways to act in criminal proceeding. With the presentation of a bibliographic review on the proposed theme, we seek to present it in a constructive way about legal regulation and its application in procedural procedures. The methodology used in this work, in addition to the review described above, used scientific articles, jurisprudence and procedural laws, whether in force or revoked. That is, it was guided by the deductive method, and which significantly results in the conclusion that when possible, the principle of specialty must be respected and used, but not for this case, since the broad defense and the contradictory in addition to structuring principles of the Democratic State of Law, is nothing more, nothing less than a defender of the dignity of those who are in the Brazilian courts.

Keywords: Drug Law; judicial interrogatory; conflict of principles; mitigation; speciality.

\section{* Doutorando e Mestre em Direitos Coletivos e Cidadania pela Universidade de Ribeirão Preto (UNAERP). Professor Universitário. Advogado. dhnunes@hotmail.com}

** Especialista em Ciências Criminais pela Faculdade de Direito da Universidade de São Paulo (USP). Advogado. jonatashet23@gmail.com

*** Especialista em Ciências Criminais pela Faculdade de Direito da USP. Advogado. adelcioramos@hotmail.com 


\section{SUMÁRIO}

INTRODUÇÃO; 1 ASPECTOS CONTEMPORÂNEOS DA LEI DE DROGAS № 11.343/2006; 1.1 Criação, conceitos e objetivos da Lei Federal no 11.343/2006; 1.2 Procedimentos processuais da Lei Federal no 11.343/2006; 2 DA AUDIÊNCIA DE INSTRUÇÃO E JULGAMENTO, O INTERROGATÓRIO DO RÉU NA LEI DE DROGAS E O CONFLITO ENTRE PRINCÍPIOS; 2.10 procedimento da audiência de instrução na

Lei de Drogas; 2.2 Os princípios e garantias constitucionais dos acusados; 2.3 Dos possíveis prejuízos causados ao acusado pela Lei Federal no 11.343/2006; 2.40 conflito dos princípios da especialidade, da ampla defesa e do contraditório; 3 ANÁLISE JURISPRUDENCIAL ACERCA DA PROBLEMÁTICA; CONSIDERAÇÕES FINAIS; REFERÊNCIAS.

\section{- INTRODUÇÃO}

A Constituição da República Federativa do Brasil de 1988, doravante chamada CRFB/1988, tem como garantias fundamentais a: ampla defesa e o contraditório, que por si só perfazem uma base principiológica para procedimentos processuais e que deste modo garantem a aquele que é acusado uma proteção as arbitrariedades do próprio Estado.

Além da Constituinte, é necessário a criação de normas infraconstitucionais, que regulamentarão a matéria processual de forma específica, seja por leis gerais (geralmente códigos processuais), ou por leis especiais, como por exemplo a Leis Federais n.o 9.099/1995 e 11.343/2006, a qual ambas trazem em seu interior normas específicas para determinadas ocasiões. Com a presente premissa, pode ocorrer o conflito entre normas, ante a regulamentação de uma situação por mais de um instrumento legal, sendo que nestes casos geralmente é utilizado o princípio da especialidade, visto que normas especiais sobrepõem normas gerais. Com a derradeira afirmação, não é espantoso que a citada situação encontre alguns obstáculos, a depender do caso concreto, sendo que um deles é tratado neste estudo.

Deste modo, como dito acima, a presente pesquisa tratará sobre a aplicação do princípio da especialidade nos crimes previstos na Lei Federal no 11.343/2006 e os eventuais conflitos que a respectiva utilização gera ao ser comparado com os princípios da ampla defesa e contraditório.

Sem expor de forma excessiva no contexto introdutório, há de se apontar que tratar-se-á de forma breve a origem da Lei de Drogas atual no território brasileiro, com observação sobre os procedimentos processuais.

Por sua vez, avançando, será analisado o fator determinante aos eventuais conflitos entre os princípios acima expostos, com olhar delicado principalmente no momento do interrogatório do réu e as possíveis consequências que este pode gerar ao denunciado se feito de um modo que afeta a ampla defesa e contraditório.

Sem postergar aos demais capítulos narrados, é neste presente momento que se explorará a premissa inicial deste trabalho, ao modo que deve ser observada de forma cuidadosa. Por fim, a análise partirá principalmente sobre o contexto jurisprudencial das principais cortes brasileiras e principalmente das decisões proferidas pelas mesmas, que 
demonstrará a situação realista a qual estamos inseridos. É sobretudo, apenas um elemento adicional a exposição feita pelo capítulo anterior, mas que não perde sua importância, visto que ela foi uns dos principais motivos que levaram a explanação anteriormente feita.

Feitas estas pontuações, imperioso destacar que o presente estudo tem como objetivo principal a análise de princípios norteadores do Direito e as consequências sofridas pelos cidadãos caso haja uma má aplicação dos mesmos.

\section{ASPECTOS CONTEMPORÂNEOS DA LEI DE DROGAS № 11.343/2006}

Com a inadequação da Lei 6.368/1976, devido ao amplo processo de descodificação do direito penal, fez que a legislação brasileira que tratava sobre as drogas ilícitas se tornasse absolutamente complexa ${ }^{1}$. Com a presente premissa, tornou-se necessária a criação de uma nova norma, que unisse em só corpo os elementos materiais e processuais. Com isto, surge a Lei no 11.343/2006.

\subsection{Criação, conceitos e objetivos da Lei Federal no 11.343/2006}

A Lei Federal no 11.343 foi sancionada em 23 de agosto de 2006 e é a atual Lei Antitóxicos, revogando as Leis no 6.368/76 e 10.409/2002, que tratavam do tema, como dispõe o art. 75. Além de distinguir a figura do traficante e o usuário, a lei em comento instituiu - Sistema Nacional de Políticas Públicas sobre Drogas - SISNAD, prescreveu medidas para prevenção do uso indevido e busca pela reinserção de usuários, bem como pela repressão à produção não autorizada ao tráfico ilícito².

Outra mudança, desta vez conceitual, está na alteração da denominação conferida à Lei que deixou de ser mencionada como Lei de Entorpecentes e passou a ser denominada "Lei de Drogas"3.

Neste interim, importante se faz a conceituação sobre o termo Drogas, que pode ser catalogado em diferentes categorias de diferentes áreas de conhecimento, inclusive no Direito Brasileiro ${ }^{4}$, e é feita pela derradeira Lei citada, considerando como drogas as substâncias ou os produtos capazes de causar dependência, assim especificados em lei ou

\footnotetext{
${ }^{1}$ CARVALHO, Salo de. A política criminal de drogas no Brasil: estudo criminológico e dogmático da Lei 11.343/06. 7. ed. São Paulo: Saraiva, 2014. Disponível em: < https://app.saraivadigital.com.br/leitor/ebook:580883>. Acesso em: 03 jan. 2020.

${ }^{2}$ Gonçalves, Victor Eduardo Rios. Legislação penal especial. 8. ed. São Paulo: Saraiva, 2011. pág. 31.

${ }^{3}$ LINS, Emmanuela Vilar. A nova Lei de Drogas e o usuário: a emergência de uma política pautada na prevenção, na redução de danos, na assistência e na reinserção social. Toxicomanias: incidências clínicas $e$ socioantropológicas. pág. 243-267, 2009. Disponível em: <http://books.scielo.org/id/qk/pdf/nery9788523208820-16.pdf>. Acesso em: 13 jul. 2019.

${ }^{4}$ ADIALA, J. C. Drogas, medicina e civilização na primeira república. 2011. Programa de Pós-Graduação em História das Ciências e da Saúde, Casa de Oswaldo Cruz-FIOCRUZ, 2011. Disponível em: <https://repositorio.observatoriodocuidado.org/bitstream/handle/handle/896/tese_fiocruz_julio_adiala.pdf?s equence=2\&isAllowed=y>. Acesso em: 08 jul. 2019.
} 
relacionados em listas atualizadas periodicamente pelo Poder Executivo da União, nos exatos termos do artigo 1ำ, parágrafo único da, da Lei no 11.343/2006.

Quanto a sua parte penal, além de criminalizar a mercancia das drogas, a lei tipifica em via de regra os atos meramente preparatórios para um agir criminoso, como por exemplo: adquirir e vender matéria-prima, insumo ou produto químico destinado a preparação de droga, bem como penaliza a associação para a realização dessas atividades ${ }^{5}$. A sua parte procedimental, será tratada especificamente na próxima seção.

\title{
1.2 Procedimentos processuais da Lei Federal no 11.343/2006
}

Em via de regra, utiliza-se o procedimento comum na grande maioria dos casos, e que é regulamentado pelo Código de Processo Penal (CPP), promulgado pelo Decreto-Lei no 3.689/1941 e reformulado pela Lei no 11.719, de 2008.

Além do procedimento comum, o Direito Processual Penal prevê o procedimento sumaríssimo e especial, sendo que ambos são utilizados pela Lei em comento. Há necessidade, porém, de citar que umas das principais diferenciações são encontradas no momento do interrogatório, visto que há certa distinção no ato da instrução probatória nos delitos descritos nos artigos 33 a 37 da citada norma, que trataremos futuramente e os demais tipos, a ser estudado neste tópico. Desta feita, cabe apontar que nas palavras de Jayme Walmer de Freitas a mencionada lei distingue dois procedimentos. A saber:

\begin{abstract}
A Lei preconiza dois procedimentos distintos [...]: um para o crime de porte de entorpecentes e outro para as demais infrações. Por primeiro, será analisado o rito referente ao crime de porte que, [...], reflete os ditames da Lei dos Juizados Criminais. Por segundo, analisa-se, [...], o novo procedimento concernente aos crimes mais graves $[\ldots]^{6}$.
\end{abstract}

No tocante ao crime de porte, o procedimento a ser observado deverá ser aquele regulado pela Lei $n$ o 9.099/95, ou seja, pelo procedimento sumaríssimo, nos termos do artigo 48, §1으, da Lei no 11.343/06.

Se o crime imputado ao usuário possuir pena mínima não superior a 1 (um) ano, deverá ser analisada a possibilidade de proposta de suspensão condicional do processo. A mencionada proposta deverá ser feita pelo Parquet, que poderá ser aceita ou rejeitada pelo acusado. Caso aceite, o Magistrado homologará a transação entre as partes e determinará a suspensão do processo ${ }^{7}$. Caso não aceite, o Ministério Público oferecerá ao Juiz, de imediato a denúncia, nos termos do artigo 77 da Lei 9.099/95. O Magistrado determinará a citação do acusado e o oferecimento da resposta à acusação no momento da audiência. Nesta ocasião,

\footnotetext{
5 QUEIROZ, Paulo. Comentários à lei de drogas. 2. ed. [S. I.]: Juspodivm, 2018, p. 14. Disponível em: <https://www.editorajuspodivm.com.br/cdn/arquivos/ff69af02652251017981410ba3fd300d.pdf>. Acesso em: 13 jul. 2019.

${ }^{6}$ Aspectos penal e processual penal da novíssima lei antitóxicos. Jus Navigandi, Teresina, ano 10, n. 1209, 23 out. 2006. Disponível em: <http://jus2.uol.com.br/doutrina/texto.asp?id=9074>. Acesso em: 13 jul. 2019.

${ }^{7}$ Gonçalves, Victor Eduardo Rios. Legislação penal especial. 8. ed. São Paulo: Saraiva, 2011, p. 31.
} 
o denunciado será interrogado após a oitiva das testemunhas de acusação e defesa, em harmonia ao art. 81 da supramencionada norma.

Nestes crimes, é necessário apontar que não há cominação de pena privativa de liberdade e sim de medidas ou penas alternativas ao cárcere. $O$ acusado pela posse de drogas estará sujeito a uma das penas alternativas descritas no art. 27, da Lei no 11.343/06. Importante denotar que antes de adentrar a análise ao procedimento especial, é preciso ressaltar que nem todos os delitos previstos nos artigos 33 a 39 observaram o derradeiro rito citado. É o que especifica Victor Eduardo Rios Gonçalves:

Para os crimes previstos no art. 33, § 30 (oferta de droga para pessoa de seu relacionamento para consumo conjunto), e no art. 38 (prescrição ou administração culposa de droga), deverá ser adotado integralmente o rito da Lei n. 9.099/95, já que esses delitos se enquadram no conceito de infração de menor potencial ofensivo, pois suas penas máximas não excedem dois anos ${ }^{8}$.

Deste modo, cabe nos destacar que a ação é pública incondicionada. Com isso, surge a titularidade ao Ministério Público de oferecer a denúncia para início da ação penal.

Quanto a aplicação do procedimento especial, o artigo 48, §1으 da supracitada norma é enfático em determiná-lo. Já no caput deste presente artigo vislumbra-se a aplicação subsidiária do CPP - Código de Processo Penal- nos casos em que não houver disposição legal. Em sua fase investigativa, caso haja ocorrência de flagrante delito, a autoridade judiciária comunicará ao juiz competente, remetendo ao Ministério Público cópias dos autos em 24 (vinte e quatro) horas, como dispõe o art. 50, da Lei de Drogas. Saliente-se que a presente comunicação está em conformidade ao disposto no art. 5ํ, LXII, da CRFB/1988.

Achando-se o indiciado preso, o alusivo inquérito policial deverá ser concluído no prazo de 30 (trinta) dias e caso esteja solto, no prazo de 90 (noventa) dias, com possibilidade de prorrogação pelo mesmo período, nos termos do art. 51, parágrafo único, da Lei de Drogas. Após a conclusão do Inquérito Policial e recebidos os autos em juízo, dar-se-á vista ao Ministério Público para que tome no prazo de 10 (dez) dias umas das seguintes medidas: (i) requerer o arquivamento; (ii) requisitar as diligências que entender necessárias e (iii) oferecer denúncia. É o que impõe o artigo 54 e seus incisos, da Lei Federal no 11.343/2006.

Caso o Órgão Ministerial ofereça denúncia, será determinada a notificação pessoal do acusado, para que este no prazo de 10 dias apresente a defesa prévia, como determina o artigo 55 da Lei de Drogas. Na presente ocasião, conforme a disposição processual, o réu poderá arguir preliminares e exceções e utilizar todos os argumentos com intuito de que o juiz não receba a denúncia. Pontua-se que nesta defesa o denunciado deverá oferecer os documentos e arrolar as suas testemunhas (até cinco).

Oferecida a Defesa Prévia pelo acusado, o Juiz no prazo de 05 (cinco) dias poderá aceitar, rejeitar a denúncia ou determinar a realização de diligências que entenda imprescindíveis no prazo de 10 (dez) dias para a última hipótese. O recurso cabível contra a decisão que rejeita a denúncia é o Recurso em Sentido Estrito, disposto no art. 581, inciso I, do CPP - Código de Processo Penal. Percebe-se que é a primeira citação da subsidiariedade

${ }^{8}$ Legislação penal especial. 8. ed. São Paulo: Saraiva, 2011, pág. 64. 
aplicada pelo CPP - Código de Processo Penal à Lei de Drogas, visto que na derradeira não há menção de um recurso específico com a mesma finalidade.

Por fim, caso o juiz acate a denúncia, designará audiência de instrução e julgamento, com citação do acusado e intimação das partes. Mencionado ato na instrução probatória será estudado em oportunidade própria futuramente. Entretanto, não podemos deixar de citar que a Lei Federal no 11.343/2006 ao permitir que a Lei Federal no 9.099/1995 regulasse algum dos seus tipos penais, possibilitou que o interrogatório do acusado fosse 0 último ato da instrução probatória, o que por si só garante mais proteção ao denunciado. 0 que se deve indagar é que, se ela possibilita uma maior aplicação protetiva a delitos de menor expressão, por qual razão deveria mitigar tal ampliação aos delitos mais graves? O que se parece é que foi feita uma inovação legislativa ou um mal acompanhamento de normas processuais e que na prática resultam na ineficiência da ampla-defesa.

Desta feita, é notável que a busca por uma inovação legislativa no âmbito processual ou seu incorreto acompanhamento maculou as garantias constitucionais reservadas aos acusados de terem cometido crimes dispostos na Lei de Drogas. Isto devido a inovação legislativa impor ao acusado uma barreira da qual este não consegue alcançar o contraditório e ampla-defesa. É o que se verá em seguida.

\section{DA AUDIÊNCIA DE INSTRUÇÃO E JULGAMENTO, O INTERROGATÓRIO DO RÉU NA LEI DE DROGAS E O CONFLITO ENTRE PRINCÍPIOS}

No decorrer dessa pesquisa, foi-se citado sobre os possíveis prejuízos causados aos réus nos delitos 33 a 39 da Lei Federal no 11.343/2006. Isso em razão da nova disposição da predita norma. Buscou-se, com afinco, ao longo das anteriores laudas construir um caminho explicativo, que demonstrasse os atuais procedimentos processuais.

Reportadas declarações foram necessárias para pormenorizar o assunto a ser tratado neste tópico, que conterá em seu seio o motivo na qual construiu-se a exibida análise. Menciona-se que nos demais capítulos houve críticas ao modelo adotado pela Lei de Drogas, mas não tão aprofundadas como neste momento. Sendo assim, analisar-se-á o procedimento processual da Lei de Drogas a partir da audiência de instrução e julgamento.

\subsection{O procedimento da audiência de instrução na Lei de Drogas}

É sabido que a audiência de instrução e julgamento deve ser regida pela regra da concentração dos atos processuais ${ }^{9}$. No tocante a Lei de Drogas, a audiência de instrução deve ser realizada dentro dos 30 (trinta) dias seguintes ao recebimento da peça acusatória ${ }^{10}$.

\footnotetext{
9 TÁVORA, Nestor; ALENCAR, Rosmar Rodrigues. Curso de direito processual penal. 11. ed. Salvador: Editora Podivm, 2016. p. 1668.

${ }^{10}$ Art. 56. § 20 A audiência a que se refere o caput deste artigo será realizada dentro dos 30 (trinta) dias seguintes ao recebimento da denúncia, salvo se determinada a realização de avaliação para atestar dependência de drogas, quando se realizará em 90 (noventa) dias. Disponível em: <http://www.planalto.gov.br/ccivil_03/decretolei/del3689.htm>. Acesso em: 14 jul. 2019.
} 
No caso de dependência de drogas do acusado, será determinada a realização de avaliação e, de conseguinte, a audiência será designada no prazo de noventa dias contados da data do recebimento da denúncia ${ }^{11}$. Seguindo a determinação do art. 57 da Lei Federal no 11.343/2006, após ser aberta a audiência de instrução e julgamento, será procedido de forma inicial o interrogatório do acusado.

Apontada conduta cerceia os meios de defesa do denunciado, sendo que a disposição processual do art. 400, do CPP - Código de Processo Penal- seria mais benéfica ao mesmo, em razão da ampliação e garantia do devido processo legal e o respeito a dignidade do acusado. Porém, devido ao princípio da especialidade, vem-se utilizando conforme a legislação extravagante, que por ora vem ser comentada neste artigo.

O presente ato (interrogatório), possui tamanha dimensão, que se destaca como também meio de defesa ao denunciado. É o que se extrai desta citação:

O interrogatório é considerado um meio de defesa do réu, sendo este um ato personalíssimo, um ato próprio do acusado que não deve ser passível renúncia. É considerado um meio de prova, pois o acusado irá justamente alegar sua defesa com as informações necessárias ${ }^{12}$.

Por sua vez, Vicente Greco Filho discorre:

O entendimento mais aceito sobre a natureza do interrogatório é o de que é ele ato de defesa, porque pode nele esboçar-se a tese de defesa e é a oportunidade para o acusado apresentar sua versão dos fatos, mas é, também, ato de instrução, porque pode servir como prova $^{13}$.

Por mencionada razão, o poder Estatal, com observação as garantias do réu, deverá sempre proporcionar o melhor caminho para que os atos de defesa se concretizem durante o processo judicial. Infelizmente, o presente poder Estatal ao criar a atual Lei de Drogas, equivocou-se na aplicação de garantias constitucionais. É sabido que a alteração dada pela Lei Federal no 11.719/2008 é posterior a Lei de Drogas. Entende-se assim, que a lei especial seguiu o tratamento dispensado pelo CPP - Código de Processo Penal antes de sua reforma quanto ao interrogatório do acusado ${ }^{14}$, ou seja, seguiu um CPP-Código de Processo Penal autoritário e com ideais fascistas, já que sua criação se deu em plena vigência ditatorial.

\footnotetext{
11 TÁVORA, Nestor; ALENCAR, Rosmar Rodrigues. Curso de direito processual penal. 11. ed. Salvador: Editora Podivm, 2016. p. 1668.

12 CAPEZ, Fernando, apud CASTILHO, Lauro Sodré de Falcão. A incompatibilidade do instrumento do interrogatório na lei de drogas com o código de processo penal. Repositório Institucional Tiradentes. Aracaju: Unit, 2015. Trabalho de conclusão de curso, Faculdade de Direito, Universidade Tiradentes, 2015, p. 11.

${ }^{13}$ GRECO FILHO, Vicente. Manual de processo penal. 11.ed. São Paulo: Saraiva, 2015. p. 249. Disponível em: < https://integrada.minhabiblioteca.com.br/\#/books/9788502219588/cfi/250!/4/4@0.00:53.9>. Acesso em: 14 jul. 2019.

${ }^{14}$ MANTOANI, Célia Terezinha; DE DEUS, Cássia Lissani. O exercício do contraditório e da ampla defesa no interrogatório do réu no procedimento da lei 11.343/06. Anuário Pesquisa e Extensão Unoesc Videira, v. 1, p. 9, 2016.
} 
Destaca-se assim, que com a reforma no CPP, houve uma nova observação aos ditames constitucionais, já que o interrogatório do réu foi imposto como último ato da instrução. Deste modo, foi reconhecido, ainda que indiretamente, que as normas que a antecediam a reforma foram promulgadas em Regime Militar, violavam a constituinte. Vide o que fala Mantovani e De Deus:

\begin{abstract}
Todavia, com o advento da Lei 11.719/2008, trouxe diversas alterações no Código de Processo Penal, a fim de adequá-lo com os ditames da Constituição Federal de 1988, tendo em vista que o antigo CPP foi editado sob a égide do Estado Totalitário, necessitando, assim, alterações dos procedimentos para se adequar ao atual Estado de Direito e ao pleno exercício do contraditório e da ampla defesa. Assim, a lei especial conservou a redação de seu art. 57, mantendo o interrogatório do réu como primeiro ato da audiência de instrução e julgamento, em respeito ao princípio da especialidade $^{15}$.
\end{abstract}

Neste escopo, surgem diversos questionamentos e imbróglios no ponto de vista jurídico no tocante ao que se deve prevalecer: (i) as garantias constitucionais ou (ii) princípio da especialidade? Isto dependerá da interpretação doutrinária e jurisprudencial acerca do assunto. $\mathrm{O}$ que não deve ocorrer, é o resgate das características de um sistema inquisitivo, que rejeita e ignora as disposições da Lei Maior.

Conforme o texto legal, após o interrogatório do acusado, serão ouvidas as testemunhas: primeiro as arroladas pela acusação e depois, as indicadas pela defesa ${ }^{16}$. A seguir, o Ministério Público e o Defensor do denunciado terão vinte minutos cada, prorrogáveis por mais dez minutos para alegações finais orais. Feito isto, o Magistrado proferirá a sentença caso possível ou ordenará que os autos the sejam conclusos para no prazo de dez dias, proferi-la ${ }^{17}$.

Percebe-se que com o interrogatório sendo o primeiro ato da audiência de instrução, há a real possibilidade do cerceamento de defesa e aplicação dos resquícios do sistema processual inquisitivo, uma vez o que "o processo não é visto como um instrumento para alcançar a verdade e fazer justiça, mas tão somente como um meio para fazer atuar o Direito Penal" ${ }^{\prime 18}$.

\title{
2.2 Os princípios e garantias constitucionais dos acusados
}

Tornar-se acusado de um processo criminal em nosso ordenamento jurídico não impõe automaticamente a perda ao direito de proclamar para si os princípios e as garantias constitucionais. Explana-se assim a irrevogabilidade das normas constitucionais condizentes a

\footnotetext{
15 Ibid., p. 10.

${ }^{16}$ TÁVORA, Nestor; ALENCAR, Rosmar Rodrigues. Curso de direito processual penal. 11. ed. Salvador: Editora Podivm, 2016, p. 1669.

${ }^{17}$ Legislação penal especial. 8. ed. São Paulo: Saraiva, 2011, p. 69.

18 NORES, José I. Cafferata. Manual de derecho procesal penal. 3. ed. Córdoba, Advoca-tus, 2012, p. 202, apud MARCÃO, Renato. Curso de processo penal. Disponível em: < https://integrada.minhabiblioteca.com.br/\#/books/9788547229245/cfi/87!/4/4@0.00:22.8>. Acesso em: 14. jul. 2019.
} 
característica humana do denunciado. Atualmente, com a adoção do sistema acusatório, consegue-se distinguir as funções de acusar, defender aquele que é acusado e julgar. Essas funções devem necessariamente serem feitas por sujeitos dessemelhantes. Além da repartição de funções, é possível destacar outras características:

(i) ativação da causa pelas partes; (ii) independência e imparcialidade do Juiz (iii) liberdade de defesa e igualdade de posição entre as partes; (iv) contraditório; (v) publicidade e oralidade do procedimento; (vi) presunção de inocência; (vii) livre apresentação de provas pelas partes ${ }^{19}$.

Ainda que respectivo autor não faça menção a garantia constitucional da ampla defesa e do mega princípio da dignidade da pessoa humana, a abordaremos neste tópico. Entre as características citadas, aprofundaremos nos princípios do contraditório, e a presunção de inocência do acusado, pois como os demais acima, formam uma linha defensiva ao réu quando este é acusado pelo poder estatal. Desta feita, iniciaremos o estudo dos princípios e garantias mencionados pelo último descrito, ou seja, o da presunção de inocência.

O princípio da presunção de inocência não surgiu com o advento da CRFB/1988, visto que em 1764, Beccaria, na sua obra "Dos Delitos e das Penas" pontuava que "um homem não pode ser chamado réu antes da sentença do juiz, e a sociedade só lhe pode retirar a proteção pública após ter decidido que ele violou os pactos por meio dos quais ela lhe foi outorgada" ${ }^{20}$. Atualmente encontra respaldo no art. 5ㅇ, LVII, da CRFB/1988, sendo a mesma a primeira a tratar explicitamente sobre o assunto ${ }^{21}$. Destarte, a interpretação que se dá a este princípio é de que somos presumivelmente inocentes, ficando a encargo da acusação o ônus probatório desta demonstração. O cerceamento cautelar da liberdade só pode ocorrer em situações excepcionais e de estrita necessidade ${ }^{22}$. Há quem diga que a presunção de inocência é um dever de tratamento a aquele que é acusado. Saliente-se que neste sentido Aury Lopes Jr qualifica respectiva titulação em duas dimensões: interna ao processo e exterior a ele. Veja:

Na dimensão interna, é um dever de tratamento imposto - inicialmente - ao juiz, determinando que a carga da prova seja inteiramente do acusador (pois, se o réu é inocente, não precisa provar nada) e que a dúvida conduza inexoravelmente à absolvição; ainda na dimensão interna, implica severas restrições ao (ab)uso das prisões cautelares (como prender alguém que não foi definitivamente condenado?).Externamente ao processo, a presunção de inocência exige uma proteção contra a publicidade abusiva e a estigmatização (precoce) do réu. Significa dizer que a presunção de inocência (e também as garantias constitucionais da imagem, dignidade e privacidade) deve ser utilizada como verdadeiros limites

\footnotetext{
${ }^{19}$ MARQUES, José Frederico, apud MACHADO, André Augusto Mendes. A investigação criminal defensiva. 2010. Tese de Doutorado. Universidade de São Paulo, p. 76. Disponível em: < https://www.teses.usp.br/teses/disponiveis/2/2137/tde-27082009-

114835/publico/Andre_Augusto_Mendes_Machado_Dissertacao.pdf>. Acesso em: 14 jul. 2019.

${ }^{20}$ BECCARIA, Cesare Bonesana. Dos delitos e das penas. Trad. Torrieri Guimarães. São Paulo: Martin Claret, 2014, pág. 34.

${ }^{21}$ GIACOMOLLI, Nereu José. Comentário ao artigo 5 o, inciso LVII. In: CANOTILHO, J. J. Gomes; et. al. Comentários à Constituição do Brasil. São Paulo: Saraiva, 2013. p. 946.

22 TÁVORA, Nestor; ALENCAR, Rosmar Rodrigues. Curso de direito processual penal. 11. ed. Salvador: Editora Podivm, 2016. pág. 44.
} 
democráticos à abusiva exploração midiática em torno do fato criminoso e do próprio processo judicial. O bizarro espetáculo montado pelo julgamento midiático deve ser coibido pela eficácia da presunção de inocência ${ }^{23}$.

Além de dever de tratamento, é considerada soberana ao poder estatal de punir descontroladamente do Estado, impondo ao julgador a certeza sobre a culpabilidade do acusado. A seguir exposto, um trecho de Sarlet que destaca assertiva:

O direito de permanecer calado (nemo tenetur se detegere) e a presunção de inocência denotam a proeminência constitucional do direito de liberdade do acusado em face da pretensão punitiva do Estado - daí a proibição absoluta de prova ilícita em favor da acusação no processo penal. [...] A presunção de inocência e o ônus da prova da acusação impõem que a condenação penal só possa ser prolatada se o juiz se convencer da culpa para além da dúvida razoável (beyond a reasonable doubt). $\mathrm{E}$ a verificação do convencimento judicial só pode ocorrer em termos justificativos, donde a imprescindibilidade de se conjugarem, para observância da regra da presunção da inocência, o modelo de convencimento para além da dúvida razoável e o dever de motivação das decisões judiciais ${ }^{24}$.

Além do exposto, denota-se que a presunção de inocência é um princípio informador processual penal. Com isto, consegue-se delinear um processo voltado as garantias constitucionais, visto que aquele que é réu, ainda tem resguardado os seus direitos como qualquer outro cidadão. O Estado ainda que acuse alguém, tem o dever de promover as mesmas garantias, entre elas o direito de ser considerado inocente. Sobre esta passagem, de que a presunção de inocência é um princípio informador, aponta-se:

Tem-se sustentado reiteradamente, quase como um lugar comum, que a presunção de inocência tem um papel determinante como princípio informador de todo o processo penal. Assim, o Tribunal Constitucional declarou que a presunção de inocência "serve de base a todo procedimento criminal e condiciona a sua estrutura, constituindo um dos princípios cardiais do Direito Penal contemporâneo, em suas facetas substantiva e formal". Neste sentido, a presunção de inocência atuaria "como limite ao poder legislativo e como critério condicionador das interpretações das normas vigentes" 25 .

Com a importante função, demonstra-se que a presunção de inocência além de forma de tratamento é também um fator a ser analisado no momento da elaboração das normas. Por isso, com este desdobramento, indaga-se e analisa-se se a regulamentação concernente ao momento do interrogatório do acusado na Lei Federal $n=11.343 / 2006$, pois viola a presunção de inocência do réu, já que impossibilita sua defesa e cerceia o seu conhecimento total ao processo para expor sua versão.

Seguindo na linhagem de princípios, imperioso se faz tratar sobre a dignidade da

\footnotetext{
${ }^{23}$ LOPES JR, Aury. Direito processual penal. 13. ed. São Paulo. Saraiva, 2016. pág. 79.

${ }^{24}$ SARLET, Ingo Wolfgang. Curso de direito constitucional. 6. ed. São Paulo: Saraiva, 2017. pág. 905 e 908.

${ }^{25}$ BELTRÁN, Jordi Ferrer. Uma concepção minimalista e garantista da presunção de inocência. Revista Brasileira de Direito Processual Penal, v. 4, n. 1. Pág./s. 149-182, 2018.
} 
pessoa humana, que prescreve que os indivíduos são considerados como sujeitos titulares de direitos, entre eles o de ser livre. Necessário relatar que assim, a dignidade humana faz que "todo o direito seja feito pelo homem e para o homem, que constitui o valor mais alto de todo o ordenamento jurídico. Sujeito primário e indefectível do direito" 26 .

Diante disso, percebe-se a importância da dignidade da pessoa humana em nossa atualidade, que possui recentemente inclusão no rol dos princípios fundamentais e como um dos fundamentos do Estado Democrático de Direito (art. 1.ํ, III, da CRFB/1988). Destaca-se que nas palavras de Sarlet, a dignidade humana é um limite de poder e de tarefa dos poderes estatais ${ }^{27}$. Prezado continua a pontuar:

[...] a dignidade implica não apenas que a pessoa não pode ser reduzida à condição de mero objeto da ação própria e de terceiros, mas também o fato de que a dignidade constitui o fundamento e conteúdo de direitos fundamentais (negativos) contra atos que a violem ou a exponham a ameaças e riscos, no sentido de posições subjetivas que têm por objeto a não intervenção por parte do Estado e de terceiros no âmbito de proteção da dignidade. ${ }^{28}$.

Barroso destaca que a dignidade é também um princípio religioso que predispõe o respeito ao próximo, pois todas as pessoas são iguais e têm direito a tratamento igualmente digno ${ }^{29}$. Com respectivas citações percebemos a amplitude dada a este princípio em nosso ordenamento e começamos a visar as consequências por ele gerado. A primeira consequência correlacionada ao nosso trabalho se dá pelo respeito da integridade física e moral do réu. Pontuamos respectivo ponto pois é sabido que o desrespeito a uma norma constitucional, além de macular respectiva espécie, atinge a dignidade daquele que é cerceada. Com isso, o acusado poderá se sentir coagido a depor e confirmar determinados fatos, sem uma análise aprofundada dos mesmos.

Deste modo, com a vigência do art. 57, da Lei Federal no 11.343/2006, os acusados de terem cometidos os crimes tratados pela lei especial de drogas além de terem sua ampla defesa e contraditório reduzidos, foram atingidos em sua dignidade, pois verifica-se que primeiramente não houve respeito ao próximo como preconiza supramencionado Ministro Barroso, nem ocorreu um limite ao poder de acusar e julgar estatal, diante de uma imposição evidente do sistema processual inquisitório.

Tal pontuação é necessária e importante neste estudo, pois demonstra que a inversão da ordem do interrogatório não é apenas uma alteração legislativa. Trata-se de uma situação que infringe normas constitucionais e o espírito democrático, entre eles a ampla defesa e o contraditório, que pontuaremos no próximo parágrafo.

Seguindo na linhagem proposta, incumbe-nos citar que a ampla defesa e o contraditório como reiteradamente narrados, são princípios constitucionais. Contudo,

\footnotetext{
${ }^{26}$ TOBEÑAS, José Castan. Los Derechos de la Personalidad. 1952, apud ANDRADE, André Gustavo Corrêa De. O princípio fundamental da dignidade humana e sua concretização judicial. Revista da EMERJ, v. 6, n. $23,2003$. pág. 1.

27 SARLET, Ingo Wolfgang. Curso de direito constitucional. 6. ed. São Paulo: Saraiva, 2017, pág. 288.

28 Ibid., pág. 288.

29 BARROSO, Luís Roberto. Curso de direito constitucional contemporâneo: os conceitos fundamentais e a construção do novo modelo. 2. ed. São Paulo: Saraiva, 2010. pág. 257.
} 
também são considerados princípios do processo penal, que determina que as partes sejam ouvidas acerca dos elementos probatórios produzidos pela outra parte. Não obstante, possibilita a defesa de cumprir o seu papel de forma vasta ${ }^{30}$. No espectro constitucional, Sarlet afirma:

[...] o direito ao contraditório é identificado com a simples bilateralidade da instância, dirigindo-se tão somente às partes. Neste contexto, o contraditório realizasse apenas com a observância do binômio conhecimento-reação. Isto é, uma parte tem o direito de conhecer as alegações feitas no processo pela outra e tem o direito de, querendo, contrariá-las. [...] O direito à ampla defesa constitui direito do demandado. É direito que respeita ao polo passivo do processo. O direito de defesa é direito à resistência no processo e, à luz da necessidade de paridade de armas no processo, deve ser simetricamente construído a partir do direito de ação ${ }^{31}$.

Complementando tais assertivas, vide a conceituação de ambos princípios por dois renomados autores processualistas:

O contraditório pode ser inicialmente tratado como um método de confrontação da prova e comprovação da verdade, fundando-se não mais sobre um juízo potestativo, mas sobre o conflito, disciplinado e ritualizado, entre partes contrapostas: a acusação [...] e a defesa [...] em ficar livre de acusações infundadas e imune a penas arbitrárias e desproporcionadas). É imprescindível para a própria existência da estrutura dialética do processo. [...] O direito de defesa é concebido numa dupla dimensão: a) defesa técnica: ninguém pode ser acusado ou julgado sem defensor (constituído ou dativo), exercida por advogado habilitado [...] b) defesa pessoal ou autodefesa, exercida pelo próprio acusado. A defesa pessoal subdivide-se ainda em positiva (quando o réu presta depoimento ou tem uma conduta ativa frente a determinada prova, v.g. participando do reconhecimento, acareação etc.) ou negativa (utiliza o direito de silêncio ou se recusa a participar de determinada prova), concretizando o princípio do nemo tenetur se detegere (nada a temer por se deter) do art. 5o, LXIII, da CB; art. 186 do CPP; e 8.2. "g" da CADH. ${ }^{32}$.

[...] o contraditório vai abranger a garantia de influir em processo com repercussão na esfera jurídica do agente, independente do polo da relação processual em que se encontre [...] Enquanto o contraditório é princípio protetivo de ambas as partes (autor e réu), a ampla defesa - que com o contraditório não se confunde - é garantia com destinatário certo: o acusado. A defesa pode ser subdividida em: (1) defesa técnica (defesa processual ou específica), efetuada por profissional habilitado; e (2) autodefesa (defesa material ou genérica), realizada pelo próprio imputado. A primeira é sempre obrigatória. A segunda está no âmbito de conveniência do réu, que pode optar por permanecer inerte, invocando inclusive o silêncio ${ }^{33}$.

\footnotetext{
30 MANTOANI, Célia Terezinha; DE DEUS, Cássia Lissani. O exercício do contraditório e da ampla defesa no interrogatório do réu no procedimento da lei 11.343/06. Anuário Pesquisa e Extensão Unoesc Videira, v. 1, 2016. pág. 9

${ }^{31}$ SARLET, Ingo Wolfgang. Curso de direito constitucional. 6. ed. São Paulo: Saraiva, 2017, pág. 894-898.

32 LOPES JR., Aury. Direito processual penal. 13. ed. São Paulo. Saraiva, 2016. pág. 80-89.

33 TÁVORA, Nestor; ALENCAR, Rosmar Rodrigues. Curso de direito processual penal. 11. ed. Salvador: Editora Podivm, 2016. pág. 50-52.
} 
Diante a situada premissa, precioso considerar que no processo penal o acusado também promove a sua autodefesa, no momento do seu interrogatório. Assim considerando que o réu pode exercer o seu direito de defesa e que os princípios do contraditório e ampla defesa são capitais para a observância integra do devido processo legal, uma vez que estes são interligados, a aplicação de qualquer norma que impeça o acusado do seu direito de se defender diretamente das imputações deverá ser revisada ou anulada, pois além de ferir a dignidade e presunção de inocência daquele que é acusado, promove a realização de um processo injusto.

\subsection{Dos possíveis prejuízos causados ao acusado pela Lei Federal no 11.343/2006}

Em que pese a especificação da Lei de Drogas no capítulo 2, é de suma importância a análise de forma objetiva dos possíveis prejuízos causados ao acusado devido a nova interpretação processual dada pela Lei de Drogas. Com base nestes prováveis danos, conseguirá delimitar a análise dos efeitos causados pelo art. 57, da Lei de Drogas e consequências direcionadas não só ao réu e sim a todo ordenamento jurídico.

Tratar-se-á especificadamente em momento oportuno sobre: (i) da possível violação ao contraditório e ampla defesa; (ii) mais profundamente, sobre o eventual prejuízo à autodefesa; e (iii) imprecisões judiciais no tocante a qual procedimento a seguir.

Saliente-se que é possível que haja outros prováveis prejuízos quanto a inversão do momento do interrogatório para outras leis especiais (Código Penal Militar e Lei no $8.038 / 1990)$. Conquanto, trataremos apenas os teóricos prejuízos provocados pela norma supradita no texto deste subtítulo. Com essa delimitação temática e orientação sobre o percurso a ser seguido, passaremos ao próximo passo, momento em que se analisará o motivo que originou a presente pesquisa: a possibilidade de violação as normas constitucionais devido a má aplicação pelo princípio da especialidade.

Certo é que neste corpo de pesquisa, por diversas vezes se assumiu a ocorrência das possibilidades acima recontadas, porém deve-se observar diretamente a problemática discutida e suas eventuais soluções, devido sua elevada importância.

\subsection{0 conflito dos princípios da especialidade, da ampla defesa e do contraditório}

No decorrer do estudo, pode-se por muitas das vezes enxergar de forma relativa as consequências causadas pela inversão do interrogatório do acusado, promovida pela Lei Federal no 11.343/2006. Além do mais, demonstrou-se que a pontuada inversão da ordem de audiência na lei de drogas está atrelada ao sistema processual inquisitório (que ignora o contraditório e ampla defesa) e aos resquícios de normas anteriores a Lei Superior vigente (a Lei Federal no 11.343/2006 até o ano de 2008 estava em conformidade com a redação originária do Código de Processo Penal, promulgado quando vigia o Estado Novo).

A confusão processual decorre principalmente pela existência do princípio da especialidade, previsto no art. 1ํㅡ, do CPP - Código de Processo Penal. Em síntese, respectivo 
princípio determina que normas especiais devem preponderar sobre as gerais. Destaca-se as concernentes menções:

O art. 10 do CPP faz menção expressa apenas às ressalvas anteriormente trabalhadas. Todavia, face a existência de diversas leis especiais, editadas após a vigência do CPP (1ำ de janeiro de 1942), com previsão expressa de procedimento distinto, conclui-se que, por força do princípio da especialidade, a tais infrações será aplicável a respectiva legislação, aplicando-se o Código de Processo Penal apenas subsidiariamente ${ }^{34}$.

E ainda,

[...] a lei especial abarca um âmbito de aplicação mais restrito, captando um menor número de condutas típicas e ilícitas. Pode, então, ser efetuada a comparação entre os tipos penais como dois círculos concêntricos de diferentes raios, sendo maior o geral e o menor, o especial, razão pela qual, quando o tipo especial não restar caraterizado pela ausência dos elementos especializantes que formam a sua peculiar estrutura abstrata, a conduta poderá ser subsumida no tipo genérico, de natureza residual ${ }^{35}$.

Observa-se que a regra especial adiciona a regra geral um ou mais elementos complementares que interferem na aplicação da mesma, devendo preponderar sobre a segunda em casos que há conflitos entre as normas. ${ }^{36}$ É necessário que em uma situação rotineira e normal, deve-se o respeito ao prezado princípio. Contudo, deve-se atentar que o mesmo deve se basear com veneração aos princípios processuais descritos na CRFB/ 1988, bem como as demais garantias constitucionais, ou seja, a ampla defesa e o contraditório.

A Lei de Drogas está inserida na legislação especial, assim sendo, a aplicação analógica da legislação comum em regra é reservada apenas nos casos em que a norma especial se omite. Saliente-se que como reiteradas vezes já citado, a atual lei em comento detalha sobre o momento do interrogatório do acusado. Tal detalhamento determina que o interrogatório do réu seja o primeiro ato da audiência e deste modo é contrário ao exposto pelo CPP - Código de Processo Penal nos artigos 400 e 531, que prevê que a inquirição das testemunhas ocorrerá antes do interrogatório do réu. Há autores que defendem que a contrariedade mantida pela Lei Federal no 11.343/2006 e aplicação subsidiária do "códex" processual penal, como é o caso de Fernando Capez:

Importante notar que em alguns procedimentos especiais o interrogatório continua a constituir o primeiro ato da instrução (Leis n. 8.038/90 e 11.343/2006, por exemplo). Entretanto, em face do disposto no art. 394, § 5ㅇ, que prevê a aplicação subsidiária do procedimento ordinário ao rito especial (CPP, art. 394, § 5ㅇ), fatalmente haverá quem sustente que nos procedimentos especiais o interrogatório deverá também ser posterior à instrução probatória. No entanto, é importante

\footnotetext{
${ }^{34}$ LIMA, Renato Brasileiro de. Manual de processo penal. 4. ed. Salvador: Ed. JusPodivm, 2016. pág. 142.

${ }^{35}$ MASSON, Cleber Rogério. Direito penal esquematizado: parte geral. 3. ed. Rio de Janeiro: Forense; São Paulo: Método, 2010. pág. 117, apud PEREIRA, Ana Karolina Assis, 2012. pág. 31.

${ }^{36}$ PRADO, Luiz Regis. Curso de direito penal brasileiro. 13. ed. São Paulo: Revista dos Tribunais, 2014. pág. 188.
} 
considerar que as regras do procedimento ordinário somente terão incidência subsidiária $[\ldots]^{37}$.

Apontado texto acima causa uma certa estranheza, uma vez que sequer cogita a mencionar sobre as garantias constitucionais, ou seja, a ampla defesa e o contraditório. Concretamente, é sabido que há sim possibilidade de que normas encontrem suas exceções, o que poderia ser aplicada neste caso tão gritante de inconstitucionalidade e afronta a base principiológica. Nesta linha de raciocínio, é impositivo denotar que as normas especiais tratadas pela Lei de Drogas primeiramente para cumprimento de seus objetivos, devem ser filtradas conforme os princípios a elas diretamente e indiretamente ligados, pois garantem a cidadania e o cumprimento da vontade constitucional derradeira.

Desta maneira, deve-se inicialmente o legislativo observar se há inviolabilidade ou não de alguma garantia constitucional. Caso não seja no filtro legislativo, mencionado dever é estendido ao Poder Judiciário, conforme tratar-se-á futuramente. Com a contrariedade da atual Lei de Drogas a princípios dispostos na CFRB/1988, surge o questionamento sobre a inconstitucionalidade material, que resume em contrariedade de uma Lei ou ato normativo a Carta Magna. Neste interim, precioso é destacar a menção feita pelo Ministro do Supremo Tribunal Federal Luís Roberto Barroso:

A inconstitucionalidade material expressa uma incompatibilidade de conteúdo, substantiva, entre a lei ou ato normativo e a Constituição. [...] O controle material de constitucionalidade pode ter como parâmetro todas as categorias de normas constitucionais: de organização, definidoras de direitos e programáticas ${ }^{38}$.

Visto isso, percebe-se o caminho a ser tomado pelos controles de constitucionalidade. Contudo, percebe-se também a inércia de forma eficaz e ampla para utilização destes meios, uma vez que sequer há uma orientação firme a qual caminho se seguir. Discorreu assim neste tópico o que gera aplicação do princípio da especialidade quando se tem previsão legislativa equivocada sobre o assunto. Citada afronta como já narrado está no exercício do contraditório e a ampla defesa do acusado no momento de seu interrogatório judicial.

Mencionado entendimento é base a toda construção trazida até aqui, bem como a disposição clara do art. 5, LV, da CRFB/1988, que assegura aos acusados em geral tanto em processos judiciais, como em processos administrativos a aplicação concreta das referidas garantias constitucionais. Ora, se até em processos administrativos, que poderão ser revistos pelo poder Judiciário, mediante provocação, utiliza-se do contraditório e ampla defesa ${ }^{39}$, por qual razão nas ações ordinárias e especiais previstas na legislação processual penal os respectivos princípios devem ser mitigados?

\footnotetext{
${ }^{37}$ CAPEZ, Fernando. Curso de processo penal. 23. Ed. São Paulo: Saraiva, 2016. pág. 487.

${ }^{38}$ BARROSO, Luís Roberto. O controle de constitucionalidade no direito brasileiro: exposição sistemática da doutrina e análise crítica da jurisprudência. 6. ed. São Paulo: Saraiva, 2012, p. 30.

39 DI PIETRO, Maria Sylvia Zanella. Direito administrativo. Rio de Janeiro: Forense, 2018. Disponível em: <https://integrada.minhabiblioteca.com.br/\#/books/9788530976163/cfi/6/34!/4/862/6/4@0:100>. Acesso em: 28 jul. 2019.
} 
Destarte que, qualquer lei ou ato normativo que vede a utilização destas garantias deverão ser consideradas inconstitucionais. Para isso, impõe-se que nos processos penais é direito do acusado a se manifestar e ter conhecimento a todos elementos probatórios produzidos pela parte acusatória ${ }^{40}$. Surge assim a ideia da autodefesa, que pode ser promovida pelo próprio acusado em seu interrogatório:

\begin{abstract}
A chamada defesa pessoal ou autodefesa manifesta-se de várias formas, mas encontra no interrogatório policial e judicial seu momento de maior relevância. Classificamos a autodefesa a partir de seu caráter exterior, como uma atividade positiva ou negativa. $O$ interrogatório é o momento em que o sujeito passivo tem a oportunidade de atuar de forma efetiva - comissão -, expressando os motivos e as justificativas ou negativas de autoria ou de materialidade do fato que se lhe imputa $^{41}$.
\end{abstract}

Para tanto, o denunciado deve ter ciência do que lhe é imputado. Assim se considerarmos a regra da especialidade, se estará automaticamente promovendo a incapacitação do próprio denunciado em exercer a sua autodefesa. Além do mais, como o réu não tem o poder de formular indagações ou exigir a contradita das testemunhas a serem ouvidas posteriormente a seu interrogatório, ficará totalmente dependente do exercício feito pelo seu procurador, que será desenvolvida em próximo subtítulo. Surge assim, uma situação conflitante que sequer é considerada por muitos, ainda que inseridos no contexto judicial, pois de um lado, temos a pontuação da aplicação do princípio da máxima eficácia e efetividade da CRFB/1988, que implicam deveres de proteção do Estado e exercem uma função organizatória e procedimental ${ }^{42}$ e de outro a aplicação de forma especial na Lei de Drogas.

Imperioso destacar que ante a divergência doutrinária e jurisprudencial acerca do assunto, a narrativa da conciliação do rito especial tratado pela Lei de Drogas com a disposição geral do art. 400 do CPP - Código de Processo Penal é inicialmente o melhor caminho a ser considerado. Isto porque, não se busca o afastamento integral da legislação específica em todos os casos e sim, apenas naqueles que contrariem a CRFB/1988. Deste modo, cita-se como exemplo um caso que não contraria a Lei Superior, que é a apresentação da Defesa Prévia antes da citação do acusado na Lei de Drogas, conforme trata o seu artigo 55, considerando que na legislação processual geral, a citação antecede a Resposta à Acusação, nos termos do artigo 396, do CPP - Código de Processo Penal.

Contudo, a falta de um entendimento constitucional neste assunto remete a uma insegurança jurídica, especificamente no que diz a consequência de um cerceamento de defesa para um momento que pode alterar a sua vida. A insegurança jurídica ainda faz que haja uma variedade de entendimentos entre os próprios magistrados, que prejudica também as partes do processo penal, especialmente a defesa, pois se tem uma invisibilidade do procedimento a ser considerado. Deve-se destacar por fim que a conciliação dos

\footnotetext{
${ }^{40}$ MANTOANI, Célia Terezinha; DE DEUS, Cássia Lissani. O exercício do contraditório e da ampla defesa no interrogatório do réu no procedimento da Lei no 11.343/06. Anuário Pesquisa e Extensão Unoesc Videira, v. 1, 2016. pág. 9.

${ }^{41}$ LOPES JR., Aury. Direito processual penal. 13. ed. São Paulo. Saraiva, 2016. pág. 83.

${ }^{42}$ SARLET, Ingo Wolfgang; NETO, Jayme Weingartner. Constituição, direitos fundamentais e processo penal: a discussão em torno da legitimidade jurídico-constitucional da realização do interrogatório do réu no início ou ao final da instrução. Revista da AJURIS, v. 41, n. 134, 2014. pág. 327-328.
} 
procedimentos com a ocorrência do interrogatório ao final ressaltaria o dever de maximização da eficácia das normas de direitos fundamentais, após ter sido analisado cada caso ${ }^{43}$. Ou seja, a utilização de meios que garantem a maximização de direitos fundamentais com superação a regras legais deverá ser analisada concretamente e após demonstrarem condições para mesma, entre eles a não implicação a outro direito fundamental, poderão ser concebidas, produzindo ou resguardando os direitos preliminarmente tutelados.

Desta feita, "pode o interrogatório ser realizado ao final da instrução probatória em detrimento do disposto na legislação específica, sem que tal heterotopia comprometa o telos da audiência e sem que disso resulte compressão indevida de outros direitos e bens constitucionais" ${ }^{44}$. Com base neste escopo, é totalmente viável a utilização do procedimento geral ao especial proposto pela Lei Federal no 11.343/2006 no tocante ao interrogatório, pois primeiramente, a disposição legislativa poderá ser considerada inconstitucional, pois afronta a vários princípios e garantias constituintes.

Assim, percebe-se que ainda de forma indireta, aquele que é acusado poderá entender a situação jurisdicional que está inserida e com base nisto, promover a sua defesa com acessibilidade e respaldo a sua dignidade e presunção de inocência.

\section{ANÁLISE JURISPRUDENCIAL ACERCA DA PROBLEMÁTICA}

Após um longo caminho e explanação temática sobre o presente tema, verificouse que a alteração trazida pela Lei de Drogas atual impacta pontualmente a defesa técnica ou autodefesa do acusado, assim como o seu contraditório. Isto porque, conforme relatado, a mitigação impede que o denunciado conheça todos os elementos acusatórios antes de expor sua versão dos fatos.

Desta feita, verifica-se a importância temática elaborada através deste estudo e que sequer pode deixar de ser observada pelo posicionamento jurisprudencial. Tal fator ocorre ante a mutabilidade frequente das decisões proferidas em instâncias superiores, o que gera uma insegurança jurídica e dúvida aos magistrados sobre qual procedimento ser utilizado.

Sendo assim, neste presente capítulo se estudará decisões proferidas pelo Tribunal de Justiça de São Paulo, Superior Tribunal de Justiça e Supremo Tribunal Federal e as suas alterações, para evidenciar de modo concreto o exposto no parágrafo anterior.

Inicia-se pelo Tribunal de Justiça de São Paulo, o mais complexo do país. ${ }^{45}$ Inicialmente há de se verificar duas decisões que são totalmente conflitantes. A primeira segue o posicionamento firmado neste trabalho e determina a realização do interrogatório do acusado como último ato da audiência, anulando todo o procedimento a partir do interrogatório do réu. A segunda por sua vez, em que pese tenha sido julgada posteriormente

\footnotetext{
${ }^{43}$ SARLET, Ingo Wolfgang; NETO, Jayme Weingartner. Op., cit, pág. 335.

${ }^{44}$ Ibid., pág. 335.

45 SÃO PAULO (Estado). Portal do Governo. Tribunal de Justiça inicia ano judiciário em 2017. São Paulo, 2017. Disponível em: <http://www.saopaulo.sp.gov.br/spnoticias/tj-sp-inicia-ano-judiciario-de-2017/>. Acesso em: 11 ago. 2019.
} 
a primeira decisão, mantém contrariamente a mesma e afirma que não há nulidade se o interrogatório for o primeiro ato. Aprecia-se:

Tráfico de entorpecentes e posse ilegal de arma de fogo de uso restrito - Recurso defensivo - Pedidos preliminares de reconhecimento de nulidade da audiência de instrução e julgamento, por suposta ausência de fundamentação acerca da manutenção do uso de algemas pelo sentenciado e em razão do interrogatório do réu ter sido realizado antes da colheita das demais provas orais - Uso de algemas devidamente fundamentado - Instrução que se encerrou em 3.7.2017 - Concluiuse, por meio do julgamento do HC 127.900 (Relator o Min. DIAS TOFFOLI, j. em 03.06.2016), que "a norma inscrita no art. 400 do Código de Processo Penal comum aplica-se, a partir da publicação da ata do presente julgamento [3.8.2016], aos processos penais militares, aos processos penais eleitorais e a todos os procedimentos penais regidos por legislação especial incidindo somente naquelas ações penais cuja instrução não se tenha encerrado" - Nulidade reconhecida. Recurso provido para anulação do presente feito, a partir do interrogatório do réu, com o retorno dos autos à origem para que sejam renovados os atos nela praticados a partir desse momento processual. (TJSP; Apelação Criminal 000004019.2017.8.26.0573; Relator (a): Otavio Rocha; Órgão Julgador: 7ạ Câmara de Direito Criminal; Foro de Botucatu - 2a Vara Criminal; Data do Julgamento: 24/07/2019; Data de Registro: 02/08/2019) ${ }^{46}$.

Tráfico. Arguição de nulidades por cerceamento de defesa. Interrogatório realizado nos moldes do artigo 57 da Lei no 11.343/06. Primeiro ato de instrução. Violação aos princípios do devido processo legal e da ampla defesa. Inocorrência. Dispositivo não revogado pela Lei no 11.719/08. Reafirmação da especialidade do rito. Alegação de ausência de defesa técnica. Vício não configurado. Inteligência da súmula no 523 do STF. Preliminares rejeitadas. REVISÃO CRIMINAL. Tráfico e associação. Materialidade e autoria demonstradas. Prova oral e pericial. Condenação a 11 anos, 4 meses e 24 dias de reclusão, mais 1700 dias-multa, no piso, fixado o regime inicial fechado. Pretendida absolvição com fulcro no artigo 621, inciso I, do CPP. Inadmissibilidade. Decisão fundada em elementos concretos de convicção. Inocorrência de contrariedade à evidência dos autos. Penas e regimes confirmados. Privilégio não configurado. Tráfico praticado mediante associação com outros indivíduos. Evidência de dedicação a atividade criminosa. Hipótese que afasta a incidência do artigo 33, § 4으, da Lei no 11.343/06. Substituição da privativa de liberdade por restritiva de direitos. Inadmissibilidade. Multa. Inconstitucionalidade não configurada. Indeferimento. (TJSP; Revisão Criminal 0015571-84.2018.8.26.0000; Relator (a): Otávio de Almeida Toledo; Órgão Julgador: 8 Grupo de Direito Criminal; Foro de Ribeirão Bonito - Vara Única; Data do Julgamento: 06/08/2019; Data de Registro: 07/08/2019). ${ }^{47}$

Em razão dessa flacidez de posicionamentos, o Magistrado vinculado a este Tribunal possuirá dúvidas sobre qual decisão seguir, podendo em determinadas ocasiões seguir a

\footnotetext{
${ }^{46}$ BRASIL. Tribunal de Justiça de São Paulo. Apelação Criminal no 0000040-19.2017.8.26.0573, 7ạ Câmara de Direito Criminal do Tribunal de Justiça do Estado de São Paulo. São Paulo/SP, 24 de julho de 2019.

Disponível em: <https://esaj.tjsp.jus.br/cjsg/getArquivo.do?cdAcordao=12735422\&cdForo=0>. Acesso em: 11 ago. 2019.

${ }^{47}$ BRASIL. Tribunal de Justiça de São Paulo. Revisão Criminal no 0015571-84.2018.8.26.0000, 8o Grupo de Direito Criminal do Tribunal de Justiça do Estado de São Paulo. São Paulo/SP, 6 de agosto de 2019. Disponível em: <https://esaj.tjsp.jus.br/cjsg/getArquivo.do?cdAcordao=12748083\&cdForo=0>. Acesso em: 11 ago. 2019.
} 
segunda, em razão desta ser tido utilizada desde a vigência da Lei de Drogas. É o que ocorre nas audiências de instrução e julgamento. Para isso, importante comentar duas situações, que efetivamente ocorreram no Estado de São Paulo, demonstrando assim a insegurança. Vejase:

Conforme a ata de audiência do Processo no 1500061-16.2019.8.26.0066, observa-se que o interrogatório do acusado foi realizado como último ato da instrução probatória. O mesmo não se verifica na situação da ata de audiência do Processo no 0000373 85.2018.8.26.0459, que determinou o interrogatório como primeiro ato. São tais situações que ocasionam a respectiva insegurança. Como o Defensor e o réu poderão se preparar com tantas possibilidades a serem tomadas pelos Magistrados?

Neste aspecto, cita-se que o julgador via de regra mantém-se localizado em determinada localidade e ali toma decisões, que podem ser totalmente evitadas em outros locais. O advogado e o réu não mantêm o mencionado vínculo territorial e podem atuar e serem acusados, respectivamente, em diversas cidades, Estados e regiões do País.

Portanto, numa situação com suma importância como a apresentada é possível que haja tanta divergência assim? Para Rosito, o Direito em si deve buscar a diminuição das divergências jurisprudenciais. É o que se extrai desta passagem:

No entanto, embora a divergência jurisprudencial seja uma realidade inafastável, no que Kelsen tem plena razão, o Direito deve buscar minimizá-la assim como deve evitar que os entendimentos consolidados ao longo do tempo sejam repentinamente alterados, frustrando, em última análise, as expectativas dos indivíduos e da coletividade ${ }^{48}$.

Entretanto, ainda que os casos concretos apresentados ocorram em primeira instância, necessário aduzir que pelo menos uma uniformização deveria ocorrer, evitando-se medidas imorais e com puro subjetivismo. Como dito, contrariamente ao primeiro caso, o segundo caso, demonstra uma situação em que o acusado foi ouvido em primeiro ato, como determina a regra específica e por isso teve mitigada a sua defesa.

Em que pese a primeira decisão apresentada faça menção clara a decisão proferida no $\mathrm{HC}$ no 127.900, nota-se que a mesma deixa de ser utilizada no dia a dia forense (como demonstra a decisão posterior), o que ocasiona ao denunciado constantemente a injustiça e o cerceamento de sua defesa, que supracitadamente foi tratado.

Recentemente, por sua vez, o Superior Tribunal de Justiça deliberou acerca do tema em algumas situações, da qual se analisará os: (i) REsp 1.825.622 e (ii) REsp 1.808.389, para definição do rito a ser adotado pela Lei no 11.343/06 e que resultaram na decisão de afetação no tema 1027. A seguir, o tratado na anterior decisão manifestada, no REsp 1.825.622/SP, que é idêntico ao item de número dois neste parágrafo nominado. Vide decisão:

[...] LEI ANTITÓXICOS.RITO PROCESSUAL. (CPP, ART. 400 OU LEI N. 11.343/2006, ART. 57). MULTIPLICIDADE DE CASOS ASSEMELHADOS. SUSPENSÃO DOS PROCESSOS.

${ }^{48}$ ROSITO, Francisco. Teoria dos precedentes judiciais: Racionalidade da tutela jurisdicional. Curitiba: Juruá, 2012. pág.118. 
DESNECESSIDADE. RECURSO ESPECIAL AFETADO. 1. O cerne da controvérsia cingese a saber se, nos crimes previstos na Lei n. $11.343 / 2006$, deve ser aplicado o rito processual disposto no art. 400 do Código de Processo Penal, em homenagem aos princípios constitucionais do contraditório e da ampla defesa, ou o rito específico da legislação própria (art. 57 da Lei n. 11.343/2006), em razão do princípio da especialidade. 2. Diante da multiplicidade de casos semelhantes que são amiúde retratados pela mesma discussão suscitada nesta impugnação, julgados frequentemente por ambas as Turmas que compõem a Terceira Seção, e da relevância jurídica da matéria, apresento este recurso especial, para apreciação desta Terceira Seção, a fim de que o seu julgamento seja submetido ao rito dos recursos repetitivos, nos termos dos arts. 1.036 e seguintes do Código de Processo Civil e 256-I do RISTJ. 3. Não se aplica à hipótese o disposto na parte final do § 1 o do art. 1.036 do Código de Processo Civil (suspensão do trâmite dos processos pendentes), haja vista que a questão será julgada com brevidade.4. Recurso especial afetado. (ProAfR no REsp 1825622/SP, Rel. Ministro ROGERIO SCHIETTI CRUZ, TERCEIRA SEÇÃO, julgado em 24/09/2019, DJe 15/10/2019) ${ }^{49}$

Até o dia 03 de agosto de 2016 o Supremo Tribunal Federal mantinha posição de que o acusado deveria ser interrogado em primeiro ato da audiência caso o procedimento especial a ele vinculado determinasse. É o que se extrai do HC 125094/MG:

[...] 1. O Supremo Tribunal Federal sedimentou o entendimento segundo o qual não é cabível habeas corpus contra decisão que indefere medida cautelar no bojo de idêntico remédio constitucional na instância inferior, ex vi do enunciado n. 691 da Súmula do STF: "[não compete ao Supremo Tribunal Federal conhecer de habeas corpus impetrado contra decisão do relator que, em habeas corpus requerido a tribunal superior, indefere a liminar." 2. A alteração promovida pela Lei $n$. 11.719/2008 não alcança os crimes descritos na Lei 11.343/2006, em razão da existência de rito próprio normatizado neste diploma legislativo. 3. A jurisprudência desta Corte é pacífica no sentido de que as novas disposições do Código de Processo Penal sobre o interrogatório não se aplicam a casos regidos pela Lei das Drogas. Precedentes: ARE 823822 AgR, Relator(a): Min. GILMAR MENDES, Segunda Turma, julgado em 12/08/2014; HC 122229, Relator(a): Min. RICARDO LEWANDOWSKI, Segunda Turma, julgado em 13/05/2014. 4. In casu, a realização de interrogatório no início da instrução processual não enseja constrangimento ilegal a ser sanado na via do habeas corpus, notadamente quando ainda pendente de análise impetração na instância a quo. 4. Agravo regimental a que se nega provimento. (HC 125094 AgR, Relator(a): Min. LUIZ FUX, Primeira Turma, julgado em 10/02/2015, PROCESSO ELETRÔNICO DJe-041 DIVULG 03-03-2015 PUBLIC 04-03-2015) ${ }^{50}$.

Como acima dito, a própria corte alterou o seu posicionamento, consoante o HC no 127.900/AM. Em decisão do Plenário da Corte, fixou a tese de que o interrogatório deve ser o último ato realizado na audiência de instrução e julgamento, após ser ouvida a

49 BRASIL. Superior Tribunal de Justiça. Recurso Especial no 1825622/SP da Terceira Seção, Brasília, DF, 15/10/2019. Disponível

em: <https://scon.stj.jus.br/SCON/jurisprudencia/toc.jsp?livre=TEMA+1027\&b=ACOR\&thesaurus=JURIDICO\&p=true $>$. Acesso em: 28 fev. 2019. (itálico nosso).

${ }^{50}$ BRASIL. Supremo Tribunal Federal. Habeas Corpus no 125094/MG da Primeira Turma, Brasília, DF, 10/02/2015. Disponível

em: <http://stf.jus.br/portal/jurisprudencia/visualizarEmenta.asp?s1=000222838\&base=baseAcordaos>. Acesso em: 11 ago. 2019. (itálico nosso). 
Defensoria Pública da União, que relembrou o entendimento da respectiva Corte Suprema no julgamento da AP 528, que na ocasião reconheceu que o rito ordinário era mais benéfico à defesa ${ }^{51}$. Analisa-se a presente ementa do HC 127.900/AM abaixo:

[...] Adequação do sistema acusatório democrático aos preceitos constitucionais da Carta de República de 1988. Máxima efetividade dos princípios do contraditório e da ampla defesa (art. 5o, inciso LV). Incidência da norma inscrita no art. 400 do Código de Processo Penal comum aos processos penais militares cuja instrução não se tenha encerrado, o que não é o caso. Ordem denegada. Fixada orientação quanto a incidência da norma inscrita no art. 400 do Código de Processo Penal comum a partir da publicação da ata do presente julgamento, aos processos penais militares, aos processos penais eleitorais e a todos os procedimentos penais regidos por legislação especial, incidindo somente naquelas ações penais cuja instrução não se tenha encerrado. 1. [...] 3. Nulidade do interrogatório dos pacientes como primeiro ato da instrução processual (CPPM, art. 302). 4. A Lei no 11.719/08 adequou o sistema acusatório democrático, integrando-o de forma mais harmoniosa aos preceitos constitucionais da Carta de República de 1988, assegurando-se maior efetividade a seus princípios, notadamente, os do contraditório e da ampla defesa (art. 5ㅇ, inciso LV). 5. Por ser mais benéfica (lex mitior) e harmoniosa com a Constituição Federal, há de preponderar, no processo penal militar (Decreto-Lei no 1.002/69), a regra do art. 400 do Código de Processo Penal. 6. De modo a não comprometer o princípio da segurança jurídica (CF, art. 5ำ XXXVI) nos feitos já sentenciados, essa orientação deve ser aplicada somente aos processos penais militares cuja instrução não se tenha encerrado, o que não é o caso dos autos, já que há sentença condenatória proferida em desfavor dos pacientes desde 29/7/14. 7. Ordem denegada, com a fixação da seguinte orientação: a norma inscrita no art. 400 do Código de Processo Penal comum aplica-se, a partir da publicação da ata do presente julgamento, aos processos penais militares, aos processos penais eleitorais e a todos os procedimentos penais regidos por legislação especial incidindo somente naquelas ações penais cuja instrução não se tenha encerrado. (HC 127900, Relator(a): Min. DIAS TOFFOLI, Tribunal Pleno, julgado em 03/03/2016, PROCESSO ELETRÔNICO DJe161 DIVULG 02-08-2016 PUBLIC 03-08-2016) ${ }^{52}$. (itálico nosso)

Ainda que a presente decisão do Supremo Tribunal Federal tenha consolidado uma tese na qual constava divergência, verifica-se que na prática forense, como demonstrado anteriormente nos processos citados, ainda há determinação que o interrogatório do acusado seja o primeiro ato da audiência.

Tais situações, além de atingirem os princípios outrora citados e analisados, afeta diretamente a decisão proferida pelo Corte Máxima de Justiça Brasileira. Com isso, surge divergências em todo o território nacional, ficando a defesa do acusado em uma situação de sorte, visto que a depender do Magistrado, Câmara ou Turma, terá mitigado ou não o exercício

\footnotetext{
${ }^{51}$ MAGALHÃES, ABBY ILHARCO. Unificação do momento do interrogatório do réu no processo penal após a Lei $n$. 11. 719/08: Reflexão pós-positivista e análise criminológica sobre anos de contradição do Supremo Tribunal Federal e até que enfim uma mudança de rumos. Rio de Janeiro. Escola de Magistratura do Estado de Rio Janeiro, 2016. pág. 30-31.

52 BRASIL. Supremo Tribunal Federal. Habeas Corpus no 127.900/AM do Tribunal Pleno, Brasília, DF, 03/08/2015. Disponível em:

http://www.stf.jus.br/portal/jurisprudencia/visualizarEmenta.asp?s1=000255849\&base=baseAcordaos >. Acesso em: 11 ago. 2019.
} 
de ampla defesa e contraditório, o que já anteriormente citado, gera a insegurança e embaraço jurídico, que de modo direto afetam a liberdade daquele que é acusado.

Sendo assim, o que se espera com os entendimentos firmados pelo Supremo Tribunal Federal e Superior Tribunal de Justiça, que comungam do mesmo entendimento, é que de modo unânime seja prevalecido o rito ordinário na questão construída neste presente trabalho, inutilizando a regra disposta no art. 57 da Lei Federal no 11.343/2006, e aplicandose o art. 400 do CPP, por este ter um caráter constitucional e democrático, que é essencial ao denunciado.

\section{- CONSIDERAÇÕES FINAIS}

Ante o apresentado, notou-se a suma importância do interrogatório do acusado, pois além de prova a ser constituída nos autos, é considerada meio de defesa do denunciado. Pela derradeira razão discutiu-se sobre os eventuais prejuízos causados ao acusado diante a previsão na Lei de Drogas, que regulamentou de forma contrária disposição expressa ao Código de Processo Penal.

Inicialmente, foi averiguado que evolução legislativa nem sempre foi benéfica ao denunciado, conforme foi demonstrado no escopo desta pesquisa. A atual Lei de Drogas de forma significativa causou um imbróglio processual, pois seguiu à risca o que determinava o CPP - Código de Processo Penal a época em que foi promulgada. Nesta esteira, dois anos após foram introduzidas novas normas que determinavam que o interrogatório do réu fosse o último ato da instrução. Ainda que na época houvesse a previsão legal no próprio CPP, não era viável que a atual Lei de Drogas baseasse a sua estrutura processual com base apenas nesta norma. Antes a isso, deveria orientar a norma hierárquica superior a si, ou seja, a CRFB/ 1988, pois ali encontraria respaldo e orientações a serem observadas e tomadas para a construção de regras processuais.

Sendo assim, percebe-se que o equívoco legislativo ao se orientar no então vigente Código de Processo Penal fez que o princípio da ampla defesa e contraditório fossem mitigados em razão de uma má utilização do princípio da especialidade. Se não fosse assim, o próprio STF - Supremo Tribunal Federal, não teria reconhecido na derradeira decisão que deveria utilizar a norma geral para os delitos pontuados na Lei de Drogas. O que não se pode negar é que, em que pese tenha sido determinado pela instância máxima de justiça a supracitada utilização do Código de Processo Penal, na prática forense diária ainda é possível encontrar magistrados que utilizam a forma legal descrita. Estas situações só geram uma insegurança jurídica que comprometem os mecanismos de defesa.

\section{REFERÊNCIAS}

BARROSO, Luís Roberto. Curso de direito constitucional contemporâneo: os conceitos fundamentais e a construção do novo modelo. 2. ed. São Paulo: Saraiva, 2010. 
O controle de constitucionalidade no direito brasileiro: exposição sistemática da doutrina e análise crítica da jurisprudência. 6. ed. São Paulo: Saraiva, 2012.

BECCARIA, Cesare Bonesana. Dos delitos e das penas. Trad. Torrieri Guimarães. São Paulo: Martin Claret, 2014, pág. 34.

BELTRÁN, Jordi Ferrer. Uma concepção minimalista e garantista da presunção de inocência. Revista Brasileira de Direito Processual Penal, v. 4, n. 1, pág. 149-182, 2018.

BOITEUX, Luciana. A Nova Lei Antidrogas e o aumento da pena do delito de tráfico de entorpecentes. Boletim IBCCRIM, São Paulo, v. 14, n. 167, pág. 1-6, 2006.

CAPEZ, Fernando, apud CASTILHO, Lauro Sodré de Falcão. A incompatibilidade do instrumento do interrogatório na lei de drogas com o código de processo penal. Repositório Institucional Tiradentes. Aracaju: Unit, 2015. Trabalho de conclusão de curso, Faculdade de Direito, Universidade Tiradentes, 2015, pág. 11.

. Curso de Direito Penal: Legislação Penal Especial. 4. ed. São Paulo: Saraiva,

2006.

. Curso de Processo Penal. 23 ed. São Paulo: Saraiva, 2016.

DI PIETRO, Maria Sylvia Zanella. Direito administrativo. Rio de Janeiro: Forense, 2018. Disponível em: <https://integrada.minhabiblioteca.com.br/\#/books/9788530976163/cfi/6/34!/4/862/6/4@ 0:100>. Acesso em: 28 jul. 2019.

FREITAS, Jayme Walmer de. Aspectos penal e processual penal da novíssima lei antitóxicos. Jus Navigandi, Teresina, ano 10, n. 1209, 23 out. 2006. Disponível em: <http://jus2.uol.com.br/doutrina/texto.asp?id=9074>. Acesso em: 13 jul. 2019.

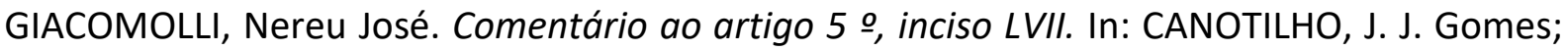
et. al. Comentários à Constituição do Brasil. São Paulo: Saraiva, 2013.

GONÇALVES, Victor Eduardo Rios. Legislação penal especial. 8. ed. São Paulo: Saraiva, 2011.

GRECO FILHO, Vicente. Manual de processo penal. 11.ed. São Paulo: Saraiva, 2015. pág. 249. Disponível em: https://integrada.minhabiblioteca.com.br/\#/books/9788502219588/cfi/250!/4/4@0.00:53.9 >. Acesso em: 14 jul. 2019.

LIMA, Renato Brasileiro de. Manual de processo penal: volume único 4. ed. Salvador: Ed. JusPodivm, 2016. 
LINS, Emmanuela Vilar. A nova Lei de Drogas e o usuário: a emergência de uma política pautada na prevenção, na redução de danos, na assistência e na reinserção social. Toxicomanias: incidências clínicas e socioantropológicas, pág./s 243-267, 2009. Disponível em: <http://books.scielo.org/id/qk/pdf/nery-9788523208820-16.pdf>. Acesso em: 13 jul. 2019.

LOPES JR, Aury. Direito processual penal. 13. ed. São Paulo. Saraiva, 2016.

MANTOANI, Célia Terezinha; DE DEUS, Cássia Lissani. O exercício do contraditório e da ampla defesa no interrogatório do réu no procedimento da Lei no 11.343/06. Anuário Pesquisa e Extensão Unoesc Videira, v. 1, 2016.

MASSON, Cleber Rogério. Direito penal esquematizado: parte geral. 3. ed. Rio de Janeiro: Forense; São Paulo: Método, 2010, pág. 117, apud PEREIRA, Ana Karolina Assis, 2012.

NORES, José I. Cafferata. Manual de derecho procesal penal. 3. ed. Córdoba, Advoca-tus, 2012, p. 202, apud MARCÃO, Renato. Curso de processo penal. Disponível em: < https://integrada.minhabiblioteca.com.br/\#/books/9788547229245/cfi/87!/4/4@0.00:22.8> . Acesso em: 14. jul. 2019.

PRADO, Luiz Regis. Curso de direito penal brasileiro. 13. ed. São Paulo: Revista dos Tribunais, 2014.

QUEIROZ, Paulo. Comentários à lei de drogas. 2. ed. [S. I.]: Juspodivm, 2018. Disponível em: $<$ https://www.editorajuspodivm.com.br/cdn/arquivos/ff69af02652251017981410ba3fd300 d.pdf>. Acesso em: 13 jul. 2019.

ROSITO, Francisco. Teoria dos precedentes judiciais: Racionalidade da tutela jurisdicional. Curitiba: Juruá, 2012.

SÃO PAULO (Estado). Portal do Governo. Tribunal de Justiça inicia ano judiciário em 2017. São Paulo, 2017. Disponível em: <http://www.saopaulo.sp.gov.br/spnoticias/tj-sp-inicia-anojudiciario-de-2017/>. Acesso em: 11 ago. 2019.

SARLET, Ingo Wolfgang. Curso de direito constitucional. 6. ed. São Paulo: Saraiva, 2017.

NETO, Jayme Weingartner. Constituição, direitos fundamentais e processo penal: a discussão em torno da legitimidade jurídico-constitucional da realização do interrogatório do réu no início ou ao final da instrução. Revista da AJURIS, v. 41, n. 134, 2014.

TÁVORA, Nestor; ALENCAR, Rosmar Rodrigues. Curso de direito processual penal. 11. ed. Salvador: Editora Podivm, 2016.

TOBEÑAS, José Castan. Los Derechos de la Personalidad. 1952, apud ANDRADE, André Gustavo Corrêa De. O princípio fundamental da dignidade humana e sua concretização judicial. Revista da EMERJ, v. 6, n. 23, 2003. 